\title{
Результаты селекции салата листового для использования в мелкотоварном производстве Ростовской области
}

\section{О.Р. Давлетбаева, А.Н. Ховрин, И.В. Барбарицкая, М.Г. Ибрагимбеков}

Дана характеристика мирового производства салата посевного, приведена его наиболее распространенная классификация. Рассказано о селекционной работе по созданию сортов салата для южных районов России, ведущейся в Агрохолдинге «Поиск». Дана характеристика созданных и переданных для регистрации в государственный реестр двух новых сортов салата Грин мастер и Грин стар.

Ключевые слова: салат листовой, салат, свежая зелень, качество, овощеводство.

алат посевной, или латук - популярная зеленная культура, имеющая большой удельный вес в мировом овощеводстве по площадям и потреблению. Потребителям он интересен из-за высокого содержания в листьях антиоксидантов и фитохимических веществ, включая кофейную кислоту и ее производные, флавонолы, витамины С и Е, каротиноиды. Листья салата при интенсивном употреблении чрезвычайно полезны для здоровья человека.

Большая часть валового сбора салата приходиться на Китай, Индию и США. Китай - крупнейший производитель салата, на его долю приходится 50\% от мирового производства. Основной тип салата, производимый и потребляемый в Китае - стеблевой салат. На долю Индии приходится 14\% посевной площади, а в США 9,1\%. В США производят три основных типа салата: айсберг, ромэн и листовой. В России салатные культуры выращиваются на площади 5,1 тыс. га [1, 2, 3].

Салат бывает разных цветов, размеров и форм. Ботанический вид Салат (Lactuca sativa L.) относят к роду Lactuca семейства Астровые (Asteraceae). Вид Lactuca sativa L. имеет следующие разновидности:

- листовой (var. crispaa) - образует розетку листьев и быстро переходящий к стеблеванию;

- срывной (var. acephala) - c poзеткой крупных листьев разной формы и окраски, более устойчив к стеблеванию;

- кочанный (var. capitata) - маслянистый или хрустящий, разный по скороспелости, форме и размеру образуемого кочана, достаточно устойчив к стеблеванию;

- ромэн (var. longifolia) - с удлиненными кочанами и овально-ланцетными довольно грубыми листьями;

- спаржевый (var. acephala) - образует растения с утолщенным стеблем, на котором расположено большое количество узких длинных листьев. Эта разновидность дает два вида продукции - одна как обычный листовой салат, другая стеблевая - как спаржа. С у щ е с т в у ю т и другие классификации [4, 5].

В России выращивание салата латука известно давно, но, в основном, в садово - огород ном использовании. В последние годы отмечается резкое повышение объемов производства этой культуры в товарном овощеводстве. В открытом грунте главным образом производят кочанные салаты типа Айсберг. В промышленных тепличных комбинатах на салатных линиях выращивают салаты Лолла росса и Батавия. Мелкие товаропроизводители в условиях открытого грунта чаще выращивают сорта Лолла росса, Лолла бионда, Батавия.

В Государственном реестре селекционных достижений на 2019 год включено 392 сорта салата отечественной и зарубежной селекции. Многообразие сортов, приспособленных к различным условиям выращивания, а также высокие вкусовые и товарные качества позволили этой культуре стать наиболее популярной среди овощных растений [3].

Агрохолдинг «Поиск» более 10 лет ведет селекционную работу по салату. Сейчас в ассортименте компании насчитывается более 18 сортов, 50\% ассортимента представлены листовыми зелеными салатами $[6,7]$. С открытием селекционного центра «Ростовский» в Ростовской области, расширились исследования по созданию сортов пригодных для юга

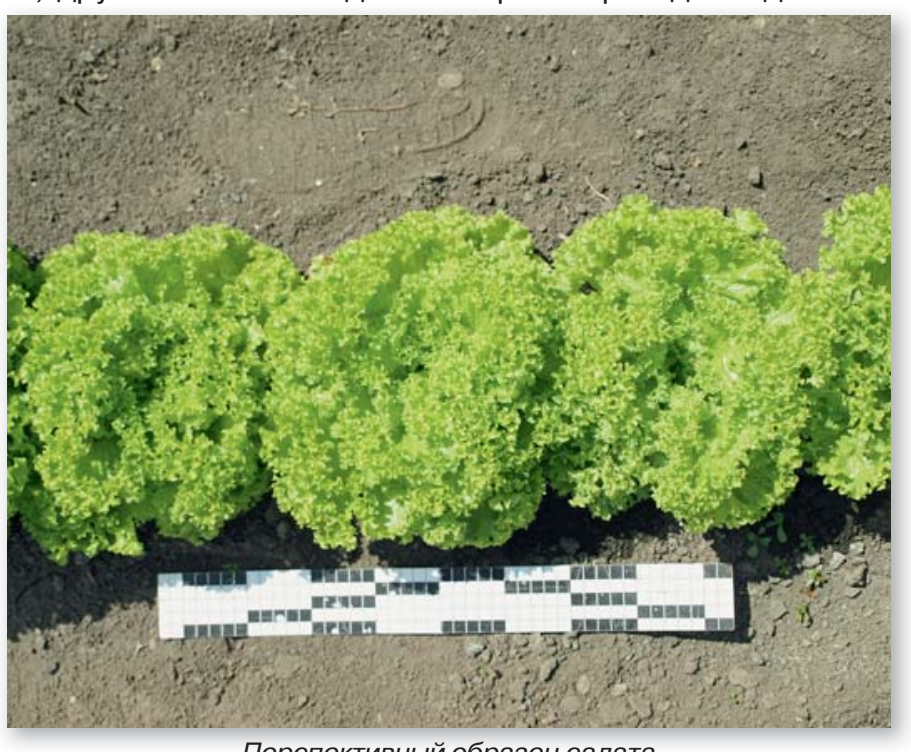

Перспективный образец салата 
России, характеризующиеся высокой урожайностью и устойчивостью к высоким температурам.

За годы исследований была сформирована коллекция салата, проверено более 150 селекционных образцов. В условиях ССЦ Ростовский выделены два перспективных образца сортотипа Lollo bionda 99/18 и 96/18, которые по результатам станционных испытаний были переданы для регистрации в государственный Реестр селекционных достижений под именами Грин мастер и Грин стар.

Грин мастер - среднеспелый сорт, имеет розетку листьев от полупрямостоячей до горизонтальной. Лист мелкий до среднего размера, округло-плоский, светло-зеленый, по краю сильноволнистый. Консистенция ткани листьев нежная, слабохрустящая. Сохраняет длительное время товарные качеств до и после уборки. Устойчив к стеблеванию. Для выращивания в открытом и защищенном грунте.

Грин стар - среднеспелый сорт, лист среднего размера, округло плоский, зеленый, волнистый по краю. Консистенция ткани листьев хрустящая. Отличается быстрым нарастанием массы листовой розетки. Устойчив к неблагоприятным факторам, долго сохраняет товарность. Для выращивания в течении всего сезона.

Цель исследований - оценка новых сортов салата сортотипа Lollo bionda в условиях мелкотоварного производства Ростовской области в защищенном и открытом грунте. Параллельно перспективные сорта испытывались в фермерском хозяйстве Ростовской области в защищенном и открытом грунте. Выращивание салатов проводили рассадным способом. Посев был в два срока: первый 15 марта для выращивания в теплице; второй - для открытого грунта 20 июня.

Рассаду салата выращивали кассетным способом в теплице. Посев семян проводили в кассеты № 90 с стандартной торфосмесью для рассады. Семена раскладывали по одному в ячейки, затем накрывали пленкой до появления всходов. Для прорастания семян температуру поддерживали на уровне $20-25^{\circ} \mathrm{C}$, при появлении семядолей температуру снижали до $15-17{ }^{\circ} \mathrm{C}$. В дальнейшем температурный режим поддерживали днем $15-17^{\circ} \mathrm{C}$, ночью $9-10{ }^{\circ} \mathrm{C}$.
За две недели до высадки рассады снижали температуру и увеличивали проветриваемость теплицы. При выращивании рассады второго срока, температурный режим обеспечивали регулярным проветриванием теплиц. Перед высадкой кассеты с рассадой поливали до такого состояния комочков, чтобы они легко извлекались из ячейки. Высаживали рассаду вручную по схеме - 15 x 30 см. В условиях первого срока посева в защищенном грунте высаживали сорокадневную рассаду, для открытого грунта - пятнадцатидневную. Сразу после высадки провели полив через систему капельного орошения (с эмиттерами через 20 см) с нормой из расчета $100 \mathrm{~m}^{3} /$ га. За 80 суток вегетации в условиях пленочной необогреваемой теплицы растения сформировали розетку диаметром: Грин мастер - 22 см и массой 177 г, Грин стар - 27 см и массой 301 г. В условиях открытого грунта при летнем выращивании на более высоком фоне температур нарастание листовой розетки проходило более интенсивно. За 48 суток роста сорт Грин Мастер сформировал розетку листьев диаметром 22 см массой 97 г, сорт Грин стар - диаметром 26 см и массой 157 г.

Убирали растения вручную. Салат срезали и упаковывали для продажи поштучно - в ящики. Перед упаковкой удаляли все не товарные листья (желтые, поврежденные).

В результате проведенных испытаний в условиях реального мелкотоварного производства фермерского хозяйства Ростовской области сорта салата сортотипа Lollo bionda Грин мастер и Грин стар показали высокую продуктивность и адаптивную способность при выращивании в пленочных теплицах и открытом грунте.

\section{Библиографический список}

1.Федеральная служба государственной статистики [Электронный ресурc] URL: https://www.gks.ru/ Дата обращения: 26.11.2019.

2.Romaine Lettuce [Электронный ресурc] URL: https:// fsi.colostate.edu/romaine-lettuce-2/. Дата обращения: 26.11.2019.

3.Шатилов М.В. и др. Производство салата - опыт в Московской области // Картофель и овощи. 2019. № 9. C. 15-17.

4.Зеленные и пряно-вкусовые культуры / Ю.П. Шевченко, В.А. Харченко, Г.С. Шевченко, А.В. Солдатенко. М.: Изд.- во ФГБНУ ФНЦО, 2019. 223 с.

5.Салат: многообразие разновидностей и сортов / М.И. Иванова, А.И. Кашлева, К.Л. Алексеева, О.Р. Давлетбаева // Картофель и овощи. 2017. № 5. С. 22-24.

6.Сорта культуры «Салат» [Электронный ресурc] URL: http://reestr.gossortrf.ru/reestr/culture/186.html. Дата обращения: 26.11.2019.

7.Давлетбаева О.Р., Ибрагимбеков М.Г., Ховрин А.Н. Новый сорт салата Поиск Ст 16 для гидропоники // Картофель и овощи. 2018. № 3. С. 39-40.

\section{Об авторах}

Давлетбаева Ольга Раисовна канд. с. - х. наук, н.с. лаборатории селекции столовых корнеплодов и луков, ВНИИО - филиал ФГБНУ ФНЦО, селекционер Агрохолдинга «Поиск». E-mail: vniioh@yandex.ru

\section{Ховрин Александр Николаевич,} канд. с. - х. наук, доцент, зав. отделом селекции и семеноводства, ВНИИО филиал ФГБНУ ФНЦО, руководитель службы селекции и первичного семеноводства Агрохолдинга «Поиск». E-mail:vniioh@yandex.ru

Барбарицкая Инна Вячеславовна, агроном-эксперт по испытаниям, ССЦ «Ростовский» Агрохолдинга «Поиск». E-mail: barbaritskaya@mail.ru ибрагимбеков Магомедрасул Гасбуллаевич, канд. С. - Х. наук, н.с. лаборатории селекции столовых корнеплодов и луков, ВНИИО филиал ФГБНУ ФНЦО, селекционер Агрохолдинга «Поиск».

E-mail:vniioh@yandex.ru

Results of selection of lettuce for use in small-scale production of the Rostov region

O.R. Davletbaeva, $P h D$, research fellow of laboratory of breeding of root crops and onions, ARRIVG - branch of FSBSI FSCVG, breeder of Poisk Agro Holding.

E-mail:vniioh@yandex.ru

A.N. Khovrin, PhD, associate professor leading research fellow, head of department of breeding and seed growing. ARRIVG branch of FSBSI FSCVG, head of department of breeding and primary seed production of Poisk Agro Holding. E-mail:vniioh@yandex.ru

I.V. Barbaritskaya, agronomist and testing expert, Rostovsky breeding centre of Poisk Agro holding. E-mail: barbaritskaya@mail.ru M.G. Ibragimbekov, PhD, research fellow of laboratory of breeding of root crops and onions, ARRIVG - branch of FSBSI FSCVG, breeder of Poisk Agro Holding.

E-mail:vniioh@yandex.ru

Summary. The characteristic of the world production of lettuce is given, its most common classification is given. It is told about the selection work on the creation of varieties of lettuce for the southern regions of Russia, conducted in the Poisk Agro Holding. The characteristic of two new varieties of Green master and Green star salad created and transferred for registration in the state register is given.

Keywords: leaf lettuce, lettuce, fresh herbs, quality, vegetable growing. 